Bangladesh J. Plant Taxon. 19(2): 201-203, 2012 (December)

(C) 2012 Bangladesh Association of Plant Taxonomists

\title{
A NEW AMORPHOPHALLUS SPECIES (ARACEAE) FROM VIETNAM
}

\author{
Xun Gong ${ }^{1}$ And Heng Li \\ Key Laboratory of Biodiversity and Biogeography, Kunming Institute of Botany, \\ Chinese Academy of Sciences, Kunming, Yunnan 650201, China \\ Keywords: Amorphophallus candidissimus; New species; Vietnam; Araceae.
}

The genus Amorphophallus Blume ex Decne. (Araceae) consists of about 200 species described from paleotropical region, including West to East Africa, South and South-east to East Asia, North Australia and Pacific islands (Li and Hetterscheid, 2010). Many new species of Amorphophallus from Tropical Asia, Africa and Madagascar have been published in the recent years (Ittenbach and Lobin, 1997; Bogner, 2003; Hetterscheid, 2011; Hetterscheid et al., 2012). There are about 16 species of Amorphophallus in the forest and hilly areas from the North to the South of Vietnam [Botany Research and Development Group of Vietnam (BVNGroup), www.botanyvn.com].

During a field work in Vietnam in 2004, a species belonging to the genus Amorphophallus was collected which did not match with any known species of the genus. After critical examination the species has been described as a new species Amorphophallus candidissimus. It has been introduced in the Kunming Botanical Garden of the Chinese Academy of Sciences, China and is growing well. After 5 years of observation we collected the inflorescence from the living plant in the garden for description. The new species Amorphophallus candidissimus is described and photographs of different parts of the species are given. The morphological similarities of the newly described species with other species are also discussed.

Amorphophallus candidissimus X. Gong et $\mathrm{H}$. Li, sp. nov.

(Fig. 1)

Type: China. Yunnan: Cultivated at Kunming Botanical Garden, Chinese Academy of Sciences [introduced from Cuc Phuong National Park, NhoQuan district, NinhBinh Province Vietnam, 15 Dec. 2004. Inflorescence: 22 Jun. 2011; Leaf: 9 Oct. 2011], Xun Gong 37521 (KUN, spiritcoll., holotype!)

Diagnosis: Amorphophalli muelleri Blume (Amorphophalli erubescenti Hett.) similis sed tubere dense verrucoso, folii lamina sine bulbilis, spatha candida, base intra laevigata, late infundibulari, $9 \mathrm{~cm}$ longa, spadice breviore, appendice alba, ovate-conica, $5 \mathrm{~cm}$ longa et $2.5 \mathrm{~cm}$ diametro differt.

Tuber depressed globose, slightly brown outside, white inside, surface densely verrucose, 3-5 $\mathrm{cm}$ high, 7-9 cm in diam. at the top, no offset development. Leaf solitary; petiole terete, $27 \mathrm{~cm}$ long, $1 \mathrm{~cm}$ in diam., smooth, uniformly pale brown with a few pale whitish oblong, with sparse elliptic spots; lamina lacking bulbils : upper side green, and lower side pale green with reddish veins, c. $40 \mathrm{~cm}$ in diam. divided into three main branches; main branches equally long; rachises once pseudodichotomously branched, naked; leaflets elliptic, elliptic-oblanceolate, 4-14 cm long, 2.5-5.5 cm wide, apex acuminate, base asymmetric and decurrent on one side, margin entire. Inflorescence long peduncled; peduncle $21 \mathrm{~cm}$ long, $11 \mathrm{~mm}$ in diam, smooth, slight brown, with scattered elliptical, whitish spots; spots c. 1-21 x 1-9 mm; spathe erect, wide infundibuliforum upperward, base convolute, without constriction in between the basal and upper portions, inner

${ }^{1}$ Corresponding author. Email: gongxun@mail.kib.ac.cn 

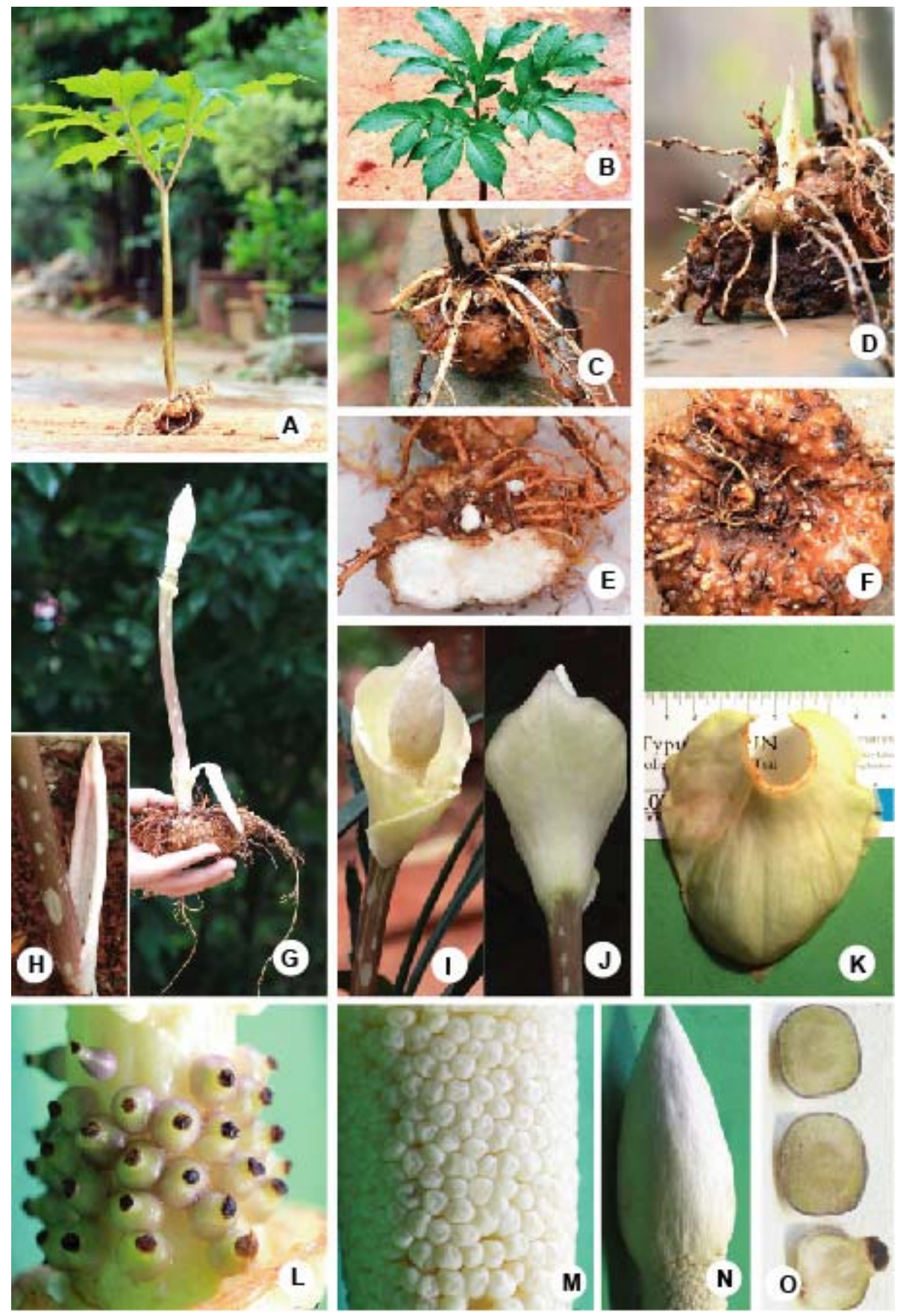

Fig. 1. Amorphophallus candidissimus X. Gong et H. Li, sp. nov., A. Plant with tuber and leaf; B. Leaf-lamina - view from top; C. Tuber with warts; D. Tuber with young vegetative shoot; E. Vertical section of tuber; F. Top-view of tuber; G. Tuber with inflorescence - spathe removed; H. Basal part of petiole and cataphyll; I. Inflorescence; J. Inflorescence - showing abaxial side of spathe; K. Detached spathe - abaxial side; L. Female zone of spadix; M. Male zone of spadix; N. Appendix of spadix; O. Female flower - cross section of ovary, and longitrdinol section. 
and outer sides white, smooth, no spots outside, base within without small warts, $9 \mathrm{~cm}$ long, 8.5 $\mathrm{cm}$ wide (when expanded), apex cuspidate with blunt tip, margin entire. Spadix sessile, leviter, longer than spathe, $10 \mathrm{~cm}$ long; female zone light pink, cylindric, c. $10 \mathrm{~mm}$ long, c. $15 \mathrm{~mm}$ in diam., flowers congested; male zone white, obconic c. $2.4 \mathrm{~cm}$ long, lower part c. $1.2 \mathrm{~cm}$ in diam, upper part c. $2.1 \mathrm{~cm}$ in diam., flowers congested; naked zone between female and male zones white, smooth, 3-4 mm long; appendix ovate-conoid, white, base smooth, without warts, c. $5 \mathrm{~cm}$ long, c. $2.5 \mathrm{~cm}$ in diam., smooth. Female flowers white, ovary subglobose, c. $2.5 \mathrm{~mm}$ high, c. 2.5 $\mathrm{mm}$ in diam., bilocular; stigma sessile, black, shallowly 3-lobed. Male flowers consisting of 2-3 thecae; each c. $1.5 \mathrm{~mm}$ long; filaments c. $1 \mathrm{~mm}$ long, fused entirely, whitish; thecae c. $0.5 \mathrm{~mm}$ long, 1.0-1.5 mm in diam., whitish, pores apical. Pollen psilate.

Distribution and habitat: Only known from the type locality, Cuc Phuong National Park, Nho Quan district, Ninh Binh province, Vietnam, ca 550-600 m above the sea level, around $20^{\circ} 21^{\prime 2} 29^{\prime \prime} \mathrm{N}, 105^{\circ} 35^{\prime} 22^{\prime \prime} \mathrm{E}$, it grows in rock crevices, and mossy tree trunk.

Etytmology: The species epithet refers to the white colour of the inflorescence, spathe and the spadix.

Notes: Amorphophallus candidissimus somewhat is related to Amorphophallus muelleri Blume from Tropical Asia (from Andamans eastward through Myanmar into northern Thailand south-eastward on Sumatra, Java, and Timor), but differs in having tuber with numerous succulent warts, the leaf lamina lacking bulbils, the spathe infundibulate, white on both sides without any spots, base within without warts, wide infundibulate upper ward, without constriction in between, $9 \mathrm{~cm}$ long, $8.5 \mathrm{~cm}$ wide, the naked zone between female and male zones at spadix present, white, smooth, 3-4 mm long; the appendix ovate-conical, white, $5 \mathrm{~cm}$ long, $2.5 \mathrm{~cm}$ in diam.

\section{Acknowledgment}

We are grateful to Professor Wu Sugong and Dr. Xiang Jiangying for their help in field investigation. We are also grateful to Dr. Yue Liangliang and Niu Yang for the photographs.

\section{References}

Bogner J. 2003. A new Amorphophallus species (Araceae) from Madagascar. Willdenowia 33: 299-303.

Hetterscheid, W.L.A. 2011. Notes on the genus Amorphophallus (Araceae). 2. New species from tropical Asia. Blumea 39: 237-281.

Hetterscheid, W.L.A., Wistuba, A., Amoroso, V.B., Medecilo, M.P. and Claudel, C. 2012. Amorphophallus natolii (Araceae), a new species from limestone on Palawan, Philippines. Botanical Studies 53: 415-420.

Ittenbach, S. and Lobin, W. 1997. Notes on the genus Amorphophallus (Araceae). 6. Six new species and two new subspecies from Africa. Willdenowia 27: 147-160.

Li, H. and Hetterscheid, W.L.A. 2010. Amorphophallus. In: Wu, Z.Y., Raven, P.H. and Hong, D.Y. (eds), Flora of China, Vol. 23 (Acoraceae through Cyperaceae). Science Press, Beijing, \& Missouri Botanical Garden Press, St. Louis, pp. 23-33. 